Ann. Biol. anim. Bioch. Biophys., 1979, 19 (5), 1499-1509.

\title{
Could hormone-induced loss of gonadotrophin receptors reduce the efficiency of superovulations stimulated by PMSG ?
}

\author{
par J. P. GOSLING, Mairead RYAN, Patricia MORGAN, \\ Department of Biochemistry, University College, Galwoy, Ireland.
}

Summary. Any future, large-scale, commercial application of embryo transfer techniques will require a continuous and reliable supply of embryos. The simplest potential method of meeting such a demand would be by superovulation using PMSG-provided treatments could be developed which are reliable and feasible in terms of cost and complexity. At present the exact requirements to modify ovulation rate in the cow are unknown. Neither are all the biological effects of treatment with PMSG understood. In an attempt to begin to clarify these areas, the literature on the biological effects of gonadotrophins, and the role of gonadotrophins in follicular development and ovulation is reviewed. In light of the very long half-life of PMSG, particular attention is paid to the ability of gonadotrophins to induce receptor loss and to desensitize target cells.

\section{Introduction.}

\section{Superovulation and follicle stimulating activity}

If embryo transfer techniques are to play a significant role in commercial cattle reproduction, reliable treatments to induce superovulation must be developed. Current superovulation treatments all rely on the use of gonadotrophins with follicle stimulating activity (Foote and Onuma, 1970 ; Sreenan and Beehan, 1976 ; Seidel et al., 1978).

Pituitary follicle stimulating hormone (FSH) is unlikely to be ever available in large enough supply at a low enough cost. Since about $30 \mathrm{mg}$ of crude FSH (Armour-P; Seidel et al., 1978) is required for one superovulation treatment, FSH extracted from 100-500 ovine or bovine pituitaries (calculated from data in Stockell Hartree 1978 and Laster, 1972) would be necessary. The efficient purification scheme of Closset and Hennan (1978) which uses porcine pituitary acetone powder as starting material, may give a better yield. Equine or human pituitaries contain up to 20 times as much FSH as ovine or bovine glands (Stockell Hartree, 1978) but are not, of course, as readily available.

The serum of pregnant mares between day 40 and day 100 of pregnancy is the major source of follicle stimulating activity available commercially. Pregnant mare serum gonadotrophin (PMSG) is prepared by selective precipitation (Passeron, 1978) 
to give a product with 1500 to $3000 \mathrm{lU} / \mathrm{mg}$ and which is approximately $20 \mathrm{p} .100$ pure (Schams and Papkoff, 1972). The concentration of PMSG is $50-100 \mathrm{IU} / \mathrm{ml}$ of pregnant mare serum and therefore 25 to $60 \mathrm{ml}$ of serum will yield sufficient partially purified PMSG (1 500-2 500 IU ; Sreenan and Beehan, 1976) to induce superovulation in one cow.

PMSG is, therefore, likely to be the sole source of follicle stimulating activity ever to be readily available in quantity; and consequently, any future widespread application of superovulation treatments would be facilitated if PMSG rather than pituitary FSH were employed.

\section{PMSG-properties and drawbacks.}

PMSG is a unique gonadotrophin in at least two respects. It has a very long halflife (50-120 hrs in cattle ; Schams ef al., 1978) due to its sialic acid content, which at 21 p. 100 on the $\beta$-subunit (Papkoff, 1974) is easily a record for gonadotrophins. In addition, as well as FSH activity, it also acts as a luteinizing or interstitial cell stimulating hormone (Papkoff, 1978).

These properties contribute to the potency and usefulness of PMSG but may also be related to its undesirable side effects. For example, in cows treated with PMSG to induce multiple ovulations, PMSG is still detectable in the circulation 6 days after the time of the induced « superovulation » (Schams ef al., 1978). Therefore, in contrast to FSH, PMSG may continue to exert an effect long after the time of treatment, and not just an FSH effect but also an $\mathrm{LH}$ effect. The disadvantages of the superovulation treatments currently employed are well documented (Sreenan and Beehan, 1976). Most employ PMSG, and in the cow the major problem is that the ovulation rates obtained are highly variable. Variations in the LH : FSH activity ratios of different batches of PMSG were suggested as being important, but this now appears unlikely (Stewart et al., 1976).

PMSG in relation to endogenous gonadotrophins.

It is our contention that a more complete understanding of the biological effects of treatment with PMSG may help in the design of improved superovulation treatments. But since PMSG treatment is intended to mimic, at a more potent level, the effects of the endogenous gonadotrophins, it is necessary to first understand the biological effects of the endogenous gonadotrophins.

In the last 5 years, it has become clear that the biological effects of gonadotrophins are extremely complex (Hseuh, 1978 ; Catt and Dufau, 1976). For example, apart from stimulating steroidogenesis, $\mathrm{LH}$ is necessary for the maintenance of target cell integrity (Dym and Madhwa Raj, 1977) and it can also desensitize the target cells to its own effects (Dufau ef al., 1978b). The great majority of relevant studies have been performed using small laboratory animals but the findings are undoubtedly of general 'significance to our understanding of factors which may influence follicular growth and ovulation in the cow. However, very few investigations of the molecular mode of action of PMSG in comparison to $\mathrm{LH}$ and FSH have been carried out, even in laboratory animals. 
The objective of this paper, therefore, is to review the recent literature on the mode of action of gonadotrophins, the regulation of cell sensitivity to gonadotrophins, and the role of gonadotrophins in follicular maturation and ovulation. In addition, the apparent ability of PMSG to regulate LH receptors willbe discussed.

\section{Biological effects of gonadotrophins.}

\section{Mechanism of action.}

Peptide and protein hormones interact with their target cells by binding to specific receptor molecules located on the outside of the cell membrane (Catt and Dufau, 1976; Shiu and Friesen, 1976). After binding, the hormone receptor complexes are internalized (Nordquist and Palmieri, 1974 ; Conn ef al., 1978) and degraded. Whether the hormone exerts any biological effect after internalization is unknown. Concomitant with occupation of the receptor, intracellular membrane bound adenyl cyclase is activated and cyclic adenosine $3^{\prime}: 5^{\prime}$-monophosphate (CAMP) synthesis from ATP is stimulated (Sutherland, 1972). Hormones having luteinizing hormone or follicle stimulating hormone activity both act in this way (Catt and Dufau, 1976) but each activity is associated with distinct and specific receptors (Kammerman ef al., 1972 ; Nimrod ef al., 1976). How the specific effects of different hormones are conveyed through a common second messenger is unknown; but it may be due to specific compartmentalization of the cAMP synthesized (Dufau ef al., 1978a). Cyclic-AMP activates intracellular protein kinases which in turn catalyse the phosphorylation of proteins, the natures of which are at present unknown. The obligatory role of cAMP in the mechanism of gonadotrophin action was given strong experimental support by the work of Dufau et al. (1977).

Regulation of target cell sensitivity.

Catt and Dufau (1973) demonstrated that, while the majority of Leydig cell, LH-specific receptors are coupled to adenyl cyclase, occupation of less than 1 p. 100 of the receptors induced a maximal stimulation of testosterone synthesis. They postulated that the role of the «spare receptors » was to maximize sensitivity. This has been supported by Conti ef al. (1977b) who found that the sensitivity of luteal cell progesterone synthesis to stimulation by human chorionic gonadotrophin (hCG) was directly related to the number of $\mathrm{LH} / \mathrm{hCG}$ receptors per cell.

In the last three years many studies have demonstrated the ability of peptide hormones to influence or control the concentration of receptors specific for the same hormone or for another hormone. The number of $\mathrm{LH} / \mathrm{hCG}$ receptors on rat Leydig cells may be dependent on, or be increased by treatment with FSH (Ketelslegers ef al., 1978), prolactin, growth hormone (Payne and Zipf, 1978) and insulin (Charreau ef al., 1978). However, treatment with LH or hCG can induce an active degradation of receptors (Hseuh ef al., 1976 ; Sharpe, 1976 ; Auclair et al., 1977 ; Purvis ef al. ; 1977 ; Tsuruhara ef al., 1977 ; Hseuh ef al., 1977 ; Haour ef al., 1977 ; Huhtaniemi ef al., 1978). Such treatments make testosterone synthesis by Leydig cells refractory to hCG stimulation (Hseuh ef al., 1977 ; Tsuruhara ef al., 1977). This occurs not only by a reduction in receptor number, but also by a desensitization of hCG-stimulatable 
adenyl cyclase, and by desensitization of steroid synthesis to stimulation by CAMP ; whether induced by cholera toxin or in the form of dibutyryl cAMP (Tsuruhara ef al., 1977). The refractoriness is spontaneously reversible and normal functions return after 6 to 14 days depending on the dose of hCG administered ( 2 to 100 IU injected intravenously; Tsuruhara et al., 1977).

The $\mathrm{LH} / \mathrm{hCG}$ receptors of corpus luteum cells are also subject to regulation by hormones. In the rat, prolactin is apparently necessary for the synthesis of a normal amount of receptor by the differentiating luteal cells (Holt ef al., 1976 ; Richards and Williams, 1976). Treatment with prostaglandin $F_{2} \alpha$ causes a decrease in receptor concentration and this is prevented by simultaneous application of prolactin (Grinwich ef al., 1976). While treatment with small amounts of hCG may have a stimulatory effect, which reflects the role of $\mathrm{LH}$ in maintaining luteal function ; treatment with larger amounts causes a dramatic decrease in the number of measurable receptors on luteal cells (Conti et al., 1976 ; Conti ef al., 1977a and 1977b). The detailed studies of Conti ef al. (1977a) indicate that, as in rat testis, this is a process of active receptor degradation. They found that occupation of 1-2 p. 100 of the receptors $5 \mathrm{hr}$ after treatment was associated with loss of 40-50 p. 100 of receptors $24 \mathrm{hr}$ after treatment. As with Leydig cells, these treatments also induce a refractoriness in the steroidogenic response, in this case hCG stimulated progesterone synthesis (Conti ef al., 1977b).

\section{Receptors and follicular development.}

The investigations of Richards and coworkers (Richards and Midgley, 1976 ; Richards et al., 1978) and others (Lindner ef al., 1977 ; Lamprecht et al., 1977 ; Ryan ef al., 1977 ; Lee, 1976) have added a new dimension to our knowledge of the control of follicular development ; namely the role of cellular sensitivity to hormone stimulation. Most of these studies involved hypophysectomy or hormone replacement therapy and, therefore, have been carried out with laboratory animals, but, since the general conclusions agree with such data as has been obtained with large animals (e.g. Lee, 1976) and since the conclusions complement and extend, rather than contradict, the classical concepts of the roles of estrogens, FSH, LH and prolactin ; they are probably relevant to the situation in humans or even cows. To quote Richards et al. (1978) ; « once the mechanisms are more clearly understood, similarities rather than differences may be revealed $\gg$.

FSH binds specifically to the granulosa cells of primordial follicles in the rat (Presl et al., 1974) and in the presence of estradiol causes granulosa cell proliferation and an increase in the number of FSH receptors on granulosa cells (Richards and Midgley, 1976). Treatment with FSH induces an increase in the density of $\mathrm{LH}$ specific receptors on granulosa cells (Zeleznik ef al., 1974 ; Richards and Midgley, 1976), and pretreatment with hCG, while having no effect by itself, potentiates and prolongs this effect (Ireland and Richards, 1978). Accordingly, we now have a picture of follicle development in which hormones interact with follicles to increase the ability of cells to respond later to stimulation by the same and/or cther hormones.

The most dramatic change that occurs is the increase in the number of $\mathrm{LH}$ specific receptors per cell, on the granulosa cells. This increase is clearly correlated with stage of cycle in rats (Nimrod et al., 1977) and with follicle size in pigs (Channing and 
Kammerman, 1973 ; Kammerman and Ross, 1975 ; Stouffer ef al., 1976 ; Lee, 1976 ; Nakano ef al., 1977), sheep (Carson et al., 1978) and cows (Gosling et al., 1977) and may therefore be regarded as a general feature of follicle growth.

Table 1 is taken from Gosling ef al., (1978) and shows the results of an experiment in which granulosa cells were incubated with increasing concentrations of ${ }^{125}$-hCG in order to characterize the $\mathrm{LH} / \mathrm{hCG}$ binding properties of the cells. The granulosa cells were obtained from antral follicles of three size classes from normal cows at slaughter. For further details see the legend of table 1 . These results and the results of other subsequent experiments (Morgan and Gosling, unpublished results), indicate that as follicles develop, their binding capacity for $\mathrm{hCG}$ or $\mathrm{LH}$ increases but that the binding affinity does not change. The most dramatic increase in the number of binding sites per cell occurs as the follicles approach preovulatory size.

TABLE 1

${ }^{125}$-hCG binding to bovine granulosa cells

\begin{tabular}{cccc}
\hline Size of follicles & Ka $\left(\mathrm{M}^{-1}\right)$ & Ka $\left(\times 10^{-10} \mathrm{M}\right) \pm \mathrm{SEM}$ & $\begin{array}{c}\text { Bniding sites per } \\
\text { cell } \pm \text { SEM }\end{array}$ \\
\hline $2-6 \mathrm{~mm}$ & $10.9 \times 10^{9}$ & $0.9 \pm 0.9$ & $140 \pm 50$ \\
$6-10 \mathrm{~mm}$ & $9.2 \times 10^{9}$ & $1.1 \pm 0.2$ & $2063 \pm 164$ \\
$>10 \mathrm{~mm}$ & $9.3 \times 10^{9}$ & $1.1 \pm 0.3$ & $4025 \pm 510$ \\
\hline
\end{tabular}

(from Gosling et al., 1978)

Ovaries were obtained fresh at the abattoir and placed immediately on ice. The animals were mostly heifers and non-pregnant. The granulosa cells were harvested by the method of Channing and Kammerman (1973) with 1 p. 100 egg albumin (Sigma grade II), $0.1 \mathrm{M}$ Sucrose, $5 \mathrm{mM} \mathrm{MgCl}_{2}$, $0.05 \mathrm{M}$ tris- $\mathrm{HCl}, \mathrm{pH} 7.5$ as buffer. Follicles which appeared in any way atretic were not used. The incubation was in a shaking water bath at $37^{\circ} \mathrm{C}$ for 6 hrs. Each tube contained $3.5 \times 10^{6}, 3.5 \times 10^{6}$ or $3.0 \times 10^{6}$ cells from small medium or large follicles respectively. ${ }^{25}$ /-hCG was prepared by lactoperoxidase catalysed iodination of hCG (Cr 119) supplied gratis by NIAMDD. The specific activity of the label was $60 \mu \mathrm{Ci} / \mu \mathrm{g}$ and it was 40 p. 100 bindable by excess rat festis $\mathrm{LH}$ receptors. Each tube contained between 0.2 to $5.0 \times 10^{-10} \mathrm{M}$ bindable ${ }^{125} \mathrm{l}$-hCG. Specific binding was estimated by including tubes corresponding to each set of conditions which also contained $5 \mu \mathrm{g}$ of hCG. Nonspecifically bound counts (less than 2 p. 100 of total label) were subtracted to give specific binding. Free label was removed after incubation by 3 centrifugal washings, and the bound fraction counted. ${ }^{125}$ l-hCG bound was plotted against total bindable ${ }^{125}$-hCG present, and fitted to a hyperbola by a least squares method to give estimates of binding per cell and binding affinity.

The exact biological purpose of this widespread property of granulosa cells from preovulatory follicles is unknown. That the receptors are biologically active is supported by the finding that hCG stimulatable adenyl cyclase increases in parallel with receptor number (Lee, 1976). There is now evidence to indicate that the preovulatory LH surge, or treatment with hCG causes the granulosa cells of preovulatory follicles to be desensitized to further stimulation by hCG (Marsh ef al., 1973 ; Hunzicker-Dunn ef al., 1976). The hCG stimulatable adenyl cyclase activity falls (Hunzicker-Dunn et al., 
1976) and so does the number of LH/hCG receptors (Richards ef al., 1976 ; Bockaert et al., 1976).

In the bovine the number of receptors per cell form the corpus luteum of midpregnancy is about 50.000 (Papaionannou and Gospodarowicz, 1975) which is considerably greater than the number per granulosa cell from bovine (4.000/cell ; Gosling ef al., 1978) or porcine (10.000/cell ; Kammerman and Ross, 1975 ; Lee, 1976) large follicles. Whether these receptor molecules are the same molecular species as the granulosa cell receptors is unknown.

\section{Biological effects of PMSG.}

PMSG cross-reacts in specific receptor assays for both LH and FSH (Stewart et al., 1976), and such systems have been employed to measure the ratio of LH to FSH activity in various commercial batches of PMSG. (Stewart et al., 1976 ; Schams ef al., 1978). The $\alpha$ subunit of PMSG will combine with the $\beta$ subunit of pituitary LH or FSH (Popkoff, 1974). Therefore, PMSG is closely related to $\mathrm{LH}$ and FSH in general molecular structure and probably all evolved from an ancestral gonadotrophin. However, in spite of the widespread use of commercial PMSG in endocrine laboratories to stimulate ovarian activity, the biological effects of PMSG as compared to LH or FSH have been little studied. In addition, results obtained in in vivo experiments are not directly comparable because of the very long half-life of PMSG. Combarnous, Ketelslegers and Hennan (1978) examined the relative affinities of porcine FSH (pFSH), pLH and PMSG for porcine testicular FSH specific and LH specific receptors. They found, that though the relative affinities of LH and PMSG for LH specific receptors were similar, the affinity of FSH specific receptor for PFSH was 4-fold greater than for PMSG. They concluded that PMSG is much more effective as a luteinizing hormone than it is as a follicle stimulating hormone.

\section{Can PMSG induce LH-receptor loss ?}

Unlike the dynamic tissues of the active ovary, rat testis interstitial cells are a relatively stable, and very well characterized, target for $\mathrm{LH}$ action. For this reason much of the work on the role of hormones in the regulation of $\mathrm{LH}$ receptors has been done with adult male rats (Dufau et al., 1978b). Therefore, in our preliminary study to examine the effects of PMSG treatment on LH receptors, we employed adult male rats (Gosling ef al., 1979). Rats of similar weight were injected subcutaneously at a single site. Two days later the rats were killed and the hCG binding capacity of the interstitial cells estimated. For further details see the caption of table 2. A two day period was chosen because from the data of others (Tsuruhara et al., 1977) receptor loss, when it occurs, is well established at this time. Table 2 (taken from Gosling ef al., 1979) shows the mean amounts of hCG bound per mg interstitial cell homogenate for each treatment. The treatments were : injection with saline, 5 IU PMSG, 50 IU PMSG or with $500 \mu \mathrm{g} \mathrm{LH}$. The data were subjected to a single factor analysis of variance and the differences between treatments were significant $(p<0.05)$. For rats treated with 50 IU PMSG the mean was significantly lower than the control $(P<0.05)$ and for $L H$ treated animals the difference was highly significant $(P<0.01)$. Treatment with 5 IU PMSG had no effect. Papkoff et al., (1978) reported that pure PMSG was equipotent 
with pure LH in a radio-receptor assay system. This would indicate that 50 IU of PMSG is equivalent to about $5 \mu \mathrm{g}$ of the ovine LH employed in the above experiment. The results of a radio-receptor analysis of the PMSG batch actually used agreed with this.

TABLE 2

Mean amounts of choriogonadotropin specifically bound to festis homogenates prepared after 2 days from treated rats

\begin{tabular}{|c|c|c|}
\hline No. of rats & Infection & $\begin{array}{l}\text { Choriogonadotropin bound } \\
\text { (fmol/mg of protein) }\end{array}$ \\
\hline \multirow[t]{2}{*}{$\begin{array}{l}5 \\
6 \\
5 \\
5\end{array}$} & $\begin{array}{l}\text { Buffer } \\
5 \text { IU PMSG } \\
50 \text { IU PMSG } \\
500 \mu g \text { oLH }\end{array}$ & $\begin{array}{l}6.21 \pm 0.35 \\
5.37 \pm 0.89 \\
3.88 \pm 0.78 * \\
2.01 \pm 0.23^{* *}\end{array}$ \\
\hline & & (from Gosling et al., 1979) \\
\hline \multicolumn{3}{|c|}{$\begin{array}{l}\text { The incubation was for } 3 \mathrm{hrs} \text {. The rats were killed by cervical dislocation and decapsulated testes } \\
\text { were gently homogenized in buffer and filtered through glass wool to give a solution rich in interstitial } \\
\text { cells and cell fragments. Known amounts of homogenate }(5-6 \mathrm{mg} \text { of protein) were added to each tube. } \\
\text { The concentration of hCG was } 600 \mathrm{pM} \text { which included } 20,000 \mathrm{cpm} \text { of }{ }^{125} \text {-hCG. The incubation was } \\
\text { for } 3 \mathrm{hrs} \text {. For further details see the legend of table } 1 \text {. Results above are means } \pm \text { SEM. The ovine } \\
\text { LH (NIH-LH-518) was supplied gratis by NIAMDD. *Significantly different from control (p<0.05). } \\
* * \text { Significantly different from control ( }<<0.01) \text {. }\end{array}$} \\
\hline
\end{tabular}

Therefore it appears that PMSG as well as hCG and LH can induce LH receptor loss. However, these preliminary results need to be extended. For example the extent to which the apparent loss may have been due to receptor occupancy was not determined. And to determine the relative potencies of these hormones would require a system uncomplicated by differences in clearance rates; for example an in vitro system like that proposed by Chen and Payne (1977). Neither was the time course of the effects of each trealment determined.

The degree of relevance of these results to the induction of multiple ovulation in the cow must remain for the moment indeterminate. However, the ability of treatment with PMSG to induce LH receptor loss, coupled to the susceptibility of granulosa cell and luteal cell LH receptors to desensitization plus the fact that PMSG remains in the bovine circulation for up to 12 days after treatment (Schams et al., 1978); suggest that the poor results obtained in general with superovulation treatment employing PMSG may in part be due to interference by PMSG in the normal processes of ovulation and luteinization. The finding that shortening the time of PMSG action by treatment with anti-PMSG serum tends to improve the results of superovulation treatment (Dhondt et al., 1978) is evidence in favour of this hypothesis. However, a greater understanding of the molecular processes involved may allow the development of simple treatments which are practicable on a large scale and which give reliable results.

EEC Seminar on "Ovarian stimulation and egg quality in mammals », Luynes, France, octobre 1978. 
Résumé. Toute application commerciale à grande échelle dans le futur des techniques de transfert d'embryons nécessitera un approvisionnement continu et sûr d'embryons. La méthode potentielle la plus simple pour faire face à une telle demande serait par superovulation, en utilisant PMSG - à condition que des traitements sûrs et réalisables en termes de coût et de complexité puissent être développés. Actuellement les exigences précises pour modifier le taux d'ovulation chez la vache sont inconnues. Ne sont également pas connus tous les effets biologiques du traitement avec PMSG. Afin de commencer à clarifier ces domaines, la bibliographie sur les effets biologiques des gonadotrophines et le rôle des gonadotrophines dans le développement folliculaire ef l'ovulation est passée en revue. En raison de la très longue demi-vie de $P M S G$, une attention particulière a été portée à la possibilité d'induction de perte de réceptivité et de désensibilisation des cellules-cibles par les gonadotrophines.

\section{References}

AUCLAIR C., KELLY P. A., LABRIE F., COY D. H., SCHALLY A. V., 1977. Inhibition of testicular luteinizing hormone receptor level by treatment with a potent luteinizing hormone-releasing hormone agonist or human chorionic gonadotropin. Biochem. biophys. Res. Commun., 76, 855-862.

BOCKAERT J., HUNZICKER-DUNN M., BIRNBAUMER L., 1976. Hormone-stimulated desensitization of hormone-dependent adenyl cyclase. J. biol. Chem., 251, 2653-2663.

CARSON R. S., FINDLAY J. K., BURGER H. G., 1978. Receptors for gonadotropins in the ovine follicle during growth and atresia. CHANNING C. P., SCHWARTZ N., Proceed Workshop on Ovarian follicular and corpus lutem function, Miami Beach, Florida, 1978. Plenum Press, N. Y., (in press).

CATT K. J., DUFAU M. L., 1973. Spare gonadotrophin receptors in rat testis. Nature New Biol., 244, 219-221.

CATT K. J., DUFAU M. L., 1976. Basic concepts of the mechanism of action of peptide hormones. Biol. Reprod., 14, 1-15.

CharReau E. H., CALVO J. C., TeStONE M., DE SOUZA VAlLE L. B., BARANO J. L., 1978. Insulin regulation of Leydig cell luteinizing hormone receptors. J. biol. Chem., 253, 2504-2506.

CHANNING C. P., KAMMERMAN S., 1973. Characteristics of gonadotropin receptors of porcine granulosa cells during follicle maturation. Endocrinology, 92, 531-540.

CHEN Y.-D. I., PAYNE A. H., 1977. Regulation of testicular LH receptors by homologous hormone : In vitro studies of receptor occupancy and receptor loss. Biochem. biophys. Res. Commun., 74, 1589-1596.

CLOSSET J., HENNAN G., 1978. Porcine follitropin. Isolation and characterization of the native hormone and its $\alpha$ and $\beta$ subunits. Eur. J. Biochem., 86, 105-113.

COMBARNOUS Y , HENNAN G., KETELSLEGERS J. M., 1978. Pregnant mare serum gonadotropin exhibits higher affinity for lutropin than for follitropin receptors of porcine testis. FEBS Letters, 90, 65-68.

CONN P. M., CONTI M., HARWOOD J. P., DUFAU M. L., CATT K. J., 1978. Internalization of gonadotrophin-receptor complex in ovarian luteal cells. Nature (London), 274, 598-600.

CONTI M., HARWOOD J. P., HSEUH A. J. W., DUFAU M. L., CATT K. J., 1976. Gonadotropin-induced loss of hormone receptors and desensitization of adenylate cyclase in the ovary. $J$. biol. Chem., 251, 7729-7731.

CONTI M., HARWOOD J. P., DUFAU M. L., CATT K. J., 1977a. Regulation of luteinizing hormone receptors and adenylate cyclase activity by gonadotrophin in the rat ovary. Mol. Pharmocol., 13, 1024-1032.

CONTI M., HARWOOD J. P., DUFAU M. L., CATT K. J. 1977b. Effect of gonadotropin-induced receptor regulation on biological responses of isolated rat luteal cells. J. Biol. Chem., 252, 8869-8874.

DHONDT D., BOUTERS R., SPINCEMAILLE J., CORYN M., VANDEPLASSCHE M., 1978. Control of superovulation in the bovine with a PMSG-antiserum. Theriogenology, 9, 529-534. 
DUFAU M. L., TSURUHARA T., HORNER K. A., PODESTA E., CATT K. J., 1977. Intermediate role of adenosine $3^{\prime}: 5^{\prime}$-cyclic monophosphate and protein kinase during gonadotropin-induced steroidogenesis in testicular interstitial cells. Proc. Nat. Acad. Sci. USA, 74, 3419-3423.

DUFAU M. L., HORNER K. A., HAGASHI K., TSURUHARA T., CONN P. M., CATT K. J., 1978a. Actions of choleragen and gonadotropin is isolated Leydig cells. Functional compartmentalization of the hormone-activated cyclic AMP response. J. biol. Chem., 253, 3721-3729.

DUFAU M. L., HSEUH A. J., CIGORRAGA S., BAUKAL A. J., CATT K. J., 1978b. Inhibition of Leydig cell function through hormonal regulatory mechanisms. Int. J. Androl., Suppl. 2, 193-239.

DYM M., MADWA RAJ A. G., 1977. Response of adult rat Sertoli cells and Leydig cells to depletion of luteinizing hormone and testosterone. Biol. Reprod., 17, 676-696.

FOOTE R. H., ONUMA H., 1970. Superovulation, ovum collection, culture and transfer. A review. J. Dairy Sci., 53, 1681-1692.

GOSLING J. P., MORGAN P., RYAN M., FOTTRELL P. F., 1979. Regulation of lutropin (luteinizing hormone) receptors in rat testis by pregnant mare serum gonadotropin. Biochem. Soc. Trans., 7, 57-59.

GOSLING J. P., MORGAN P., SREENAN J. M., 1978. Preliminary studies on the hCG binding properties of bovine granulosa cells. In, SREENAN J. M., CEC Semin. Control of reproduction in the cow, Galway, 1977, 225-237.

GRINWICH D. L., HICHINS M., BEHRMAN A. R., 1976. Control of the LH receptor by prolactin and prostaglandin $\left(F_{2} \alpha\right)$ in rat corpora lutea. Biol. Reprod., 14, 212-218.

HAOUR F., SANCHEZ P., GALLET D., SAEZ J. M., 1977. Désensibilisation par la gonadotrophine chorionique humaine (hCG) : mise en évidence d'un contrôle négatif des récepteurs des gonadotrophines par la hCG au niveau de cellules de Leydig du testicule. C. R. Acad. Sci. Paris, Sér. D, 284, 1429-1432.

HOLT J. A., RICHARDS J. S., MIDGLEY A. R. Jr., REICHERT L. E. Jr., 1976. Effect of prolactin on LH receptor in rat luteal cells. Endocrinology, 98, 1005-1013.

HSEUH A. J. W., 1978. Current developments in the mechanism of action of reproductive hormones. Clin. Obstef. Gynecol., 21, 53-66.

HSEUH A. J. W., DUFAU M. L., CATT K. J., 1976. Regulation of luteinizing hormone receptors in testicular intestitial cells by gonadotropin. Biochem. biophys. Res. Commun., 72, 1145-1152.

HSEUH A. J. W., DUFAU M. L., CATT K. J., 1977. Gonadotropin induced regulation of luteinizing hormone receptors and desenitization of testicular 3' : 5'-cyclic AMP and testosterone responses. Proc. Nat. Acad. Sci. USA, 74, 592-595.

HUHTANIEMI I., MORTIKAINEN A., TIKKLA L., 1978. hCG-induced changes in the number of rat testis $\mathrm{LH} / \mathrm{hCG}$ receptors. Mol. cell. Endocrinol., 11, 43-50.

HUNZICKER-DUNN M., BURNBAUMER L., 1976. Adenyl cyclase activities in ovarian tissues. IV. Gonadotrophin-induced desensitization of the lutral adenyl cyclase throughout pregnancy and pseudopregnancy in the rabbit and the rat. Endocrinology, 99, 211-222.

IRELAND J. J., RICHARDS J. S., 1978. A previously undescribed role for luteinizing hormone (LH : hCG) on follicular cell differentiation, Endocrinology, 102, 1458-1465.

KAMMERMAN S., CANFIELD R. E., KOLENA J., CHANNING C. P., 1972. The binding of iodinated hCG to porcine granulosa cells. Endocrinology, 91, 65-74.

KAMMERMAN S., ROSS J., 1975. Increase in numbers of gonatropin receptors on granulosa cells during follicle maturation. J. clin. Endocr. Metab., 41, 546-551.

KETELSLEGERS J.-M., HETZEL W. C., SHERINS R. J., CATT K. J., 1978. Developmental changes in testicular gonadotropin receptors, plasma gonadotropins and plasma testosterone in the rat. Endocrinology, 103, 212-222.

LAMPRECHT S. A., ZOR U., SOLOMON Y., KOCH Y., AHERN K., LINDNER H. R., 1977. Mechanism of hormonally induced refractoriness of ovarian adenylate cyclase to luteinizing hormone and prostaglandin $E_{2}$. J. Cyclic Nucl. Res., 3, 69-83.

LASTER D. B., 1972. Follicular development in heifers infused with follicle-stimulating hormone. J. Reprod. Ferf., 28, 285-289.

LEE C. Y., 1976. The porcine ovarian follicle. III. Development of chorionic gonadotropin receptors associated with increase in adenyl cyclase activity during follicle maturation. Endocrinology, 99, $42-48$.

LINDNER H. R., AMSTERDAM A., SALOMON Y., TSAFRIRI A., NIMROD A., LAMPRECHT S. A., 
ZOR U., KOCH Y., 1977. Intraovarian factors in ovulation : determinants of follicular response to gonadotrophins. J. Reprod. Fert., 51, 215-235.

MARSH J. M., MILLS T. M., LEMAIRE W. J., 1973. Preovulatory changes in the synthesis of cyclic AMP by rabbit graafian follicles. Biochim. biophys. Acta, 304, 197-202.

NAKANO R., AKAHORI T., KATAYAMA K., TOJO S., 1977. Binding of LH and FSH to porcine granulosa cells during follicular maturation. J. Reprod. Fert., 51, 23-27.

NIMROD A., BEDRAK E., LAMPRECHT S. A., 1977. Appearance of LH-Receptors and LH-Stimulable cyclic AMP accumulation in granulosa cells during follicular maturaion in the rat ovary. Biochem. biophys. Res. Commun., 78, 977-984.

NIMROD A., ERIKSON G. F., RYAN K. J., 1976. A specific FSH receptor in rat gronulosa cells : Properties in vitro. Endocrinology, 98, 56-64.

NORDQUIST R. E., PALMIERI G. M. A., 1974. Intracellular localization of parathyroid hormone in the kidney. Endocrinology, 95, 229-237.

PAPAIONANNOU S., GOSPODAROWICZ D., 1975. Comparison of the binding of human chorionic gonadotropin to isolated bovine luteal cells and bovine luteal plasma membranes. Endocrinology, 97, 114-124.

PAPKOFF H., 1974. Chemical and biochemical properties of the subunits of pregnant mare serum gonadotropin. Biochem. biophys. Res. Commun., 58, 397-404.

PAPKOFF H., 1978. Relationship of PMSG to the pituitary gonadotropins, 73-86. In SREENAN J. M., CEC Semin. Control of reproduction in the cow, Galway 1977, 73-86.

PAPKOFF H., BEWLEY T. A., RAMACHANDRAN J., 1978. Physicochemical and biological characterizations of pregnant mare serum gonadotropin and its subunits. Biochim. biophys. Acta, 532, 185-194.

PASSERON E. J., 1978. The production and standardization of PMSG. In SREENAN J. M., CEC Semin Control of reproduction in the cow, Galway, 1977, 87-96.

PAYNE A. H., ZIPF W. B., 1978. Regulation of leydig cell function by prolactin, growth hormone and luteinizing hormone. Int. J. Androl., Suppl. 2, 329-344.

PRESL J., POSPISIL J., FIGOROVA V., KRABEC Z., 1974. Stage-dependent changes in binding of iodinated FSH during ovarian follicle maturation in rats. Endocr. exper., 8, 291-298.

PURVIS K., TORJESEN P. A., HAUG E., HANSSON V., 1977. hCG suppression of LH receptors and responsiveness of testicular tissue to hCG. Mol. cell. Endocrinol., 8, 73-80.

RICHARDS J. S., IRELAND J. J., RAO M. C., BERNATH G. A., MIDGLEY A. R. Jr., REICHERT L. E. Jr., 1976. Ovarian follicular development in the rat: Hormone receptor regulation by estradiol, follicle stimulating hormone and luteinizing hormone. Endocrinology, 99, 1562-1570.

RICHARDS J. S., MIDGLEY A. R. Jr., 1976. Protein hormone action : A key to understanding ovarian follicular and luteal cell development. Biol. Reprod., 14, 82-94.

RICHARDS J. S., RAO M. C., IRELAND J. J., 1978. Actions of pituitary gonadotrophins on the ovary, 197-216. In CRIGHTON D. B., HAYNES N. B., FOXCROFT G. R., LAMMING G. E., Control of avulation, Butterworths, London.

RICHARDS J. S., WILLIAMS J. J., 1976. Luteal cell receptor for prolactin (PRL) and luteinizing hormone (LH) : Regulation by LH and PRL. Endocrinology, 99, 1571-1581.

RYAN R. J., BIRNBAUMER L., LEE C. Y., HUNZICKER-DUNN, 1977. Gonadotropin interactions with the gonad as assessed by receptor binding and adenyl cyclase activity, 85-152. In GREEP R. O., Reproductive physiology II, Vol. 13, Univ. Park Press, Baltimore.

SCHAMS D., MENZER C., SCHALLENBERGER E., HOFFMAN B., HAHN J., HAHN R., 1978. Some studies on pregnant mare serum gonadotropin (PMSG) and on endocrine responses after application for superovulation in cattle. In SREENAN J. M., CEC Semin. Control of reproduction in the cow, Galway, 1977, 122-143.

SCHAMS D., PAPKOFF H., 1972. Chemical and immunological studies on pregnant mare serum gonadotropin. Biochim. biophys. Acta, 236, 139-148.

SEIDEL G. E., ELDSEN R. P., NELSON L. D., BOWEN R. A., 1978. Superovulation of cattle with PMSG and FSH, 159-168. In SREENAN J. M., CEC Semin. Control of reproduction in the cow, Galway, 1977.

SHARPE R. M., 1976. hCG-induced decrease in availability of rat testis receptors. Nafure (London), 264, 644-646. 
SHIU R. P. C., FRIESEN A. G., 1976. Blockade of prolactin action by an antiserum to its receptors. Science, 192, 259-261.

SREENAN J. M., BEEHAN D., 1976. Methods of induction of superovulation in the cow and transfer results, 19-34. In ROWSON L. E. A., Egg transfer in cattle, CEC, Luxembourg. Eur 5491.

STEWART F., ALLEN W. R., MOOR R. M., 1976. Pregnant mare serum gonadotrophin : Ratio of follicle-stimulating hormone and luteinizing hormone activities measured by radioreceptor assay. J. Endocrinol., 71, 371-382.

STOCKELL HARTREE A., 1978. Structure of gonadotrophins as related to function, 91-99. In CRIGHTON D. B., HAYNES N. B., FOXCROFT G. R., LAMMING G. E., Control of ovulation, Butterworths, London.

STOUFFER R. L., TYREY L., SCHOMBERG D. W., 1976. Changes in 125 l labelled human chorionic gonadotropin (hCG) binding to porcine granulosa cells during follicle development and cell culture. Endocrinology, 99, 516-525.

SUTHERLAND E. W., 1972. Studies on the mechanism of hormone action. Science, 177, 401-408.

TSURUHARA T., DUFAU M. L., CIGORRAGA S., CATT K. J., 1977. Hormone regulation of testicular luteinizing hormone receptors. J. biol. Chem., 252, 9002-9009.

ZELEZNIK A. J., MIDGLEY A. R. Jr., REICHERT L. E. Jr., 1974. Granulosa cell maturation in the rat : Increased binding of human chorionic gonadotropin following treatment with follicle stimulating hormone in vivo. Endocrinology, 95, 818-825. 